\title{
Information asymmetries and conflict of interest during the Baring crisis, I $880-$ I $^{8} 90^{1}$
}

\author{
JUAN H. FLORES \\ University of Geneva and Figuerola Institute of History and Social Sciences, Universidad Carlos III de Madrid \\ Juan.Flores@unige.ch
}

\begin{abstract}
This article examines the potential conflict of interest of underwriters in London's foreign sovereign debt markets prior to the Baring crisis of $\mathrm{I} 890$. We describe the main sources of information for investors concerning Argentina, whose government debt default contributed to Baring's collapse, and compare them with those of the underwriters, particularly Baring's. We then present some empirical evidence using data on bond prices and underwriting fees that demonstrate that Baring did not exploit its information lead to the detriment of investors. Finally, we present historical evidence that shows that Baring foresaw default before markets did and consequently planned a bailout loan that could not be issued due to political instability in Buenos Aires.
\end{abstract}

Keywords: information asymmetries, underwriting, financial crises

JEL classification: F21, F34, G14, G15, G24, N23, N26

It's like, if you have something good to say, you say it, but if you have something bad to say, just keep your mouth shut.

- Federico Thomsen, Chief economist, ING Baring's office in Buenos Aires, 200 I

You will readily understand that in view of the aspect of affairs in the Argentine Republic, at present or for some time past, we have received numerous enquiries from our investing clients with respect to the government, city and provincial loans of that country held by them... We

1 This paper has been presented at several events. I would like to thank the following people for the comments they offered on previous versions: Marc Flandreau, Stefano Battilossi, Michael Bordo, Gerardo Della Paolera, Pablo Martin Aceña, Sebastian Nieto, Jérôme Sgard, and participants at the EHESS meeting in Istanbul 2005, the LACEA Meeting in Mexico 2006, the OFCE Seminar of Economic History in April 2007, the APHE Meeting in Lisbon in November 2007, the First EuroClio Conference and Fast-Track Initiative 'Exchanges in economic history' in Paris 2008, and the Globalization and History Conference in UCLA in April 2009. Comments made by the editor and anonymous referees were most useful. I would also like to thank the archivists at ING Baring, Archives Paribas, Crédit Lyonnais and the Rothschild archives. Financial support from the Ministry of Education and Science in Spain through the Consolider project CSD 2006-000 I6 is also acknowledged. I am solely responsible for any remaining errors. 
should be much obliged if you would favour us with any information in your power as to the present financial situation.

- Letter from Foster \& Braithwaite, broker at the London Stock Exchange, to Baring Brothers, I 890

On I6 November I 890, financial markets woke up to the news that one of the most respected merchant banks in the world, Baring Brothers, had overexposed itself by keeping a large amount of unsold and illiquid Argentine securities. It was only able to continue operations thanks to an international bailout orchestrated by the Bank of England, which injected a large amount of liquidity in order to prevent a banking panic that could have triggered an earthquake at the very centre of the international financial system, the City of London.

The Baring crisis of $\mathrm{I} 890$ has been one of the major events in the history of international finance. It had international spillovers, as it occurred during one of the major periods of financial globalisation, also considered to be the first bond era of capital markets. This episode has been studied from a number of different perspectives, and now, after more than Ioo years, it emerges once more as a reflection of the current crisis. Parallels can be drawn for a number of issues: it followed a major boom in international finance; financial intermediaries played a central role in originating and distributing a number of new securities into the markets including mortgage-backed 'cedulas'; even though Lombard Street did sound the alarm and despite the associated macroeconomic risks, investors continued to pour capital into Argentina, the country in which the international crisis originated. Finally, the British authorities had to deal with Baring's near collapse. Baring Brothers was one of the most influential merchant investment banks in London and played an important part in the lending boom. As in most cases, this boom ended with a financial crash that caused sharp falls in international trade, foreign investment and economic growth.

One main difference with our current financial architecture is the array of services that banks such as Baring offered to their clients. In a world of strong information asymmetries and in the absence of rating agencies and international organisations, those banks were in charge of monitoring, pricing, securities issuing and other related activities. Therefore, they constituted important information producers; for this purpose they sent permanent representatives all over the world and even developed their own communication systems. ${ }^{2}$

In addition, they were the first agents governments contacted when they sought funds in London. Though this dominant position in a financial sector offers a natural environment for scale economies, this also creates scope for conflicts of interest, and the Baring crisis may have been a consequence of this problem. This article

2 Case studies are described in Flandreau (I998) for Crédit Lyonnais and Liedtke (2006) for Rothschild. 
analyses this episode from a microeconomic perspective, and attempts to contribute to the literature on nineteenth-century financial markets' microeconomic structure. Finally, this article aims to improve the understanding of the Baring crisis. Previous studies have mainly dealt with macroeconomic issues and have left aside a number of important aspects related to investors' continuous enthusiasm towards Argentina despite the warning signals. We focus therefore on the information level of investors and the behaviour of financial intermediaries. On the one hand, we describe, in detail, investors' sources of information and what they published about Argentina. On the other, we analyse whether financial intermediaries properly monitored borrowing countries or whether some malfunction occurred during the lending boom. We look at whether financial intermediaries acted as 'banksters', hiding information on the solvency of Argentina in order to place additional securities and earn underwriting commissions, and whether this caused Argentina's over-indebtedness and led to its eventual default. ${ }^{3}$ Was the Baring crisis a consequence of a strong conflict of interest faced by underwriters of Argentine securities; conflict which led to investors' mistrust and the consequent sudden-stop of British capital exports to the rest of the world?

We proceed as follows. In the next section, we review the literature on the Baring crisis and on the economics of conflicts of interest in investment banking. In Section III, we demonstrate that there existed important information asymmetries among the leading underwriter, Baring, the other banks and investors. We find that investors could be aware of the deteriorating macroeconomic conditions in Argentina, but that for some reason this was not reflected in the prices of Argentinian securities. Moreover, we establish that Baring's main information advantage was the production of 'soft information' through its long-term relationship with Argentina and from direct communication with the government. In Section IV, we test the consequences of this information structure, and look for possible evidence of conflicts of interest and try to determine whether the most reputable banks played a certification role. Section V concludes.

Argentina became the favourite destination of European investors' capital during the I 88 os. Economic growth had been impressive there since the previous crisis of I 876 (Cortés Conde I979; Della Paolera I988; Cerro 2000), thereby attracting an increasing number of European immigrants. Exports were booming; agricultural profitability increased as a result of the discovery and conquest of new land, which in turn led to urban development and the construction of railways. Although Argentina had a bad debt service record similar to that of most other Latin American countries, it successfully managed to survive the I 870 s world crisis and thus to disassociate itself from the rest of the region by becoming one of the few Latin American countries to avoid

3 See recent paper on the role of financial intermediaries as possible 'banksters' in the I92os by Flandreau, Gaillard and Panizza (2010). 
default. It also achieved a stable macroeconomic environment by controlling public expenditures, by channelling external funds to finance the construction of new infrastructure and by adopting the gold standard in I 882 .

On the whole, however, this apparently prosperous economy was not as healthy as it seemed. Fiscal imbalances caused a short-term crisis in I 885 (causing fluctuations in the paper peso exchange rates, and prompting the country to abandon the gold standard), which marked the beginning of the debacle. The second half of the decade was, in fact, characterised by a deteriorating macroeconomic and financial situation - as shown, for instance, by Ford (I97I), Cortés Conde (I989), Della Paolera (1994) and Della Paolera and Taylor (200I). Some of the main indicators are presented in Table I, in which the fiscal and monetary variables clearly show a deteriorating trend. Deficits grew and were financed through borrowing, at first, and later through monetary issues, which increased due to the free banking law introduced in I887. This led to a sharp depreciation of the peso after I 888 , creating a potential liquidity imbalance because most of Argentina's public debt was denominated in hard currency. In order to avoid debt servicing difficulties, the government introduced a 15 per cent export duty in I885, increased its extraordinary revenues by selling state assets between I 887 and I890, and decided to negotiate a new loan from London to support the short-term needs of the treasury.

This situation did not deter foreign investors from continuing to bet on Argentina's economic miracle. Capital continued to flow into Argentina more than into any other Latin American country and reached a peak in I 888, two years before the crisis (Stone I999). Moreover, portfolio investment did not cease until political unrest and economic distress, including partial default in the first half of I 890 , became known to all.

There is no consensus in Argentina's abundant historiography about whether Argentina's macroeconomic policy was inappropriate and whether its debt levels were sustainable in the long run. Ford (I962), for instance, argues that the Baring

Table I. Argentina's macroeconomic indicators

\begin{tabular}{lcccccc}
\hline \hline Years & $\begin{array}{c}\text { Real } \\
\text { GDP } \\
\text { growth } \\
(\%)\end{array}$ & $\begin{array}{c}\text { Paper peso } \\
\text { depreciation } \\
(\%)\end{array}$ & $\begin{array}{c}\text { Inflation } \\
(\%)\end{array}$ & $\begin{array}{c}\text { Deficit to } \\
\text { ordinary } \\
\text { public } \\
\text { revenue }\end{array}$ & $\begin{array}{c}\text { Debt service } \\
\text { to ordinary } \\
\text { public } \\
\text { revenue }\end{array}$ & $\begin{array}{c}\text { Percentage of } \\
\text { debt service } \\
\text { paid in gold }\end{array}$ \\
\hline I 885 & 6.0 & 37.0 & 22.8 & 48.2 & 30.5 & 77.8 \\
I 886 & 0.0 & I.5 & $3 . \mathrm{I}$ & 35.0 & 50.9 & 68.0 \\
$\mathrm{I} 887$ & $\mathrm{I} 2.0$ & -2.9 & -4.0 & $\mathrm{I} 8.9$ & 43.4 & 60.7 \\
$\mathrm{I} 888$ & 9.9 & 9.6 & 0.0 & 34.9 & 47.4 & 89.5 \\
$\mathrm{I} 889$ & $\mathrm{I} 7.2$ & $2 \mathrm{I} .6$ & I9.8 & 34.4 & 62.7 & 93.3 \\
$\mathrm{I} 890$ & -4.3 & 43.3 & 40.9 & 25.4 & $\mathrm{NA}$ & $\mathrm{NA}$ \\
\hline \hline
\end{tabular}

Sources: Della Paolera (1988), Flores (2004). 
crisis was a 'crisis of development', as Argentina had to meet short-term debt service obligations, while the positive effects of investment projects on exports were longterm rather than short-term effects. He suggests that flows of capital in the r 880 os were positive and necessary for the economic growth of the country. In a similar vein, Duncan (1984) argues that although the government was perfectly aware that it could not avoid short-term default, it continued to borrow as part of a longterm development strategy. According to Duncan, the main victims of this strategy were investors.

Whether or not investors were aware that this situation would lead to a debt default is a different question. On the one hand, Wirth (I 893) argues that by I 886 investors already suspected that Argentina was over-borrowing. Joslin (I963) notes that in I 888 , the only reason the director of the London \& River Plate Bank had to explain why funds continued to flow into the country was that the interest rates prevailing in England were low. Eichengreen (I999) argues that the Baring crisis was expected. These authors agree with contemporary views. The general mood in the financial press, as we show below, was pessimistic. On the other hand, Argentina's longterm sovereign debt spreads over British consoles remained surprisingly stable during the years prior to the crisis - and only increased in the second half of $\mathrm{I} 890$. Moreover, the last national government bonds issued in I887 and I889 continued to have long maturities - I928 and I926 respectively - suggesting that debt sustainability was taken for granted. These facts suggest three possibilities: first of all, investors did not expect a crisis, continued to believe in the Argentine miracle and underestimated the risk. This seems implausible given the amount of negative information in the press and in different economic publications (see next section). Secondly, there might also have existed a moral hazard problem, whereby investors were aware of the risk involved but continued buying Argentinian bonds because they expected Baring to act as Argentina's last resort lender, as it had done in previous defaults. ${ }^{4}$ This also seems implausible, as the failure of issuers to place new securities on the markets was common in the late $\mathrm{I} 88 \mathrm{os}$; in fact, these failures were at the origin of Baring's liquidity problems. Thirdly, secondary market spreads did not only reflect investors' expectations about an incoming crisis. Evidence from the press, banks' archives and historians' works shows, for instance, that banks supported prices so that the market would remain stable and they could continue introducing additional issues. ${ }^{5}$ Moreover, the effect of banks' identity, their reputation and expected

4 Baring actively participated in the negotiation with defaulting countries and even took part in some meetings of bondholder associations and the Corporation of Foreign Bondholders. See, for instance, Costeloe (2003), Ferns (1960) and Flandreau and Flores (2010).

5 The press occasionally published articles on the banks' involvement in sustaining prices in order to create the necessary conditions to issue new loans. See, for instance, The Economist, published on 27 October I 888: 'For a long time past the unsound condition of the market for foreign securities has been notorious and before now prices would have certainly collapsed, had it not been for the support of the big financiers, who have done much to bolster up the market, because a downright 
behaviour (such as a potential conflict of interest) must be taken into account in the analysis of sovereign risk.

Financial intermediaries provided an array of services to countries looking for external funding in European financial markets, and were paid fees for each service, including an underwriting fee that depended on the risk involved and the distribution and market placement used. ${ }^{6}$ But they also played the role of rating agencies and could advise investors about the best investment opportunities (Flandreau 2003). They were considered as a source of information to ordinary investors or as a press agency, as specific relationships developed with borrowing governments, and so financial intermediaries had the possibility of communicating information that could be relevant to investors. This created scope for a conflict of interest, which could only be resolved through the market mechanism as this was a repeated game and reputation mattered. Flandreau and Flores (2009) capture this fact in the extreme case of the I820s, where the most reputable banks (measured as those with the highest capitalisation and market shares) were also those whose issues defaulted least. In their model, a highly reputable bank had no reason to exploit its informational advantage, as any bad choice would impact on its reputation and consequently on its market power. On the other hand, financial intermediaries with a low market share and no reputation to defend are prone to exploit their information advantage (selling bad securities as if they were good).

Nevertheless, market discipline alone cannot prevent conflicts of interest even among prestigious banks. We have reasons to believe that prestigious banks could, under certain circumstances, have incentives to take higher risks; and a sudden increase in competition would be the classic example (Bolton, Freixas and Shapiro, 2007). Flores $(2004,2010)$ suggests that this was the case in the 1880 s. $^{7}$ In other words, the leading bank had the incentive to decrease monitoring costs or to enter into more aggressive competition or both. Negative externalities would emerge, affecting financial markets in general and investors in particular.

The extent to which the conflict of interest affected London's late nineteenthcentury financial market has never been systematically tested. However, banking historians have already dealt with 'reputation' and the prominence of private banks such as the 'Sixth great power' (for Baring, Ziegler I988) or 'The World's banker' (for Rothschild, Ferguson I998) and their impact on capital markets. This system seems to have failed during the I880s, as the contemporary press suggests. The general impression was that underwriters had adopted irresponsible management practices and sought to deceive investors. To quote but a few examples, The Economist

break in prices would have been extremely prejudicial to the numerous financial operations which they have on hand' (a similar article was published on I 3 October, emphasising this fact).

6 There were basically two loan-issuing systems: firm taking and placement. In the second system, banks took no risk if they failed to place the bonds in the market. Today's parallel would be the so-called 'best efforts' system. Flores (2004, 20I0) provides a detailed description of both issuing systems, and Flandreau et al. (2009b) describe the long-term evolution of the underwriting of sovereign loans.

7 As Kindleberger (1978) asserts, other agents observed Baring's continuous involvement in Argentina, and thus confidently invested or underwrote additional loans. 
commented on 22 November I 890: 'Had Messrs Baring Brothers been able to shift the burden of their South American obligations upon the investment they would now have been standing erect ... it must be admitted that they did not neglect to use all the means in their power to rid themselves in this way of their liabilities.' On the same day, The Speaker came close to arguing that Baring had hidden information about Uruguay's level of floating debt (that country also defaulted), as otherwise the loan it had issued on behalf of that country 'would probably not have been a success'. Some days later, The Economist severely concluded: 'while the name of a well-known house must and should always be of value, it has never been an index to the permanence of a country's solvency, and we should learn to accept it for what it is worth, and no more'. ${ }^{8}$

\section{III}

Ferns (1960) differentiated information levels for investors and financial intermediaries, and concluded that the former depended to a large extent on the latter. In his description of how information flowed, Ferns emphasises British investors' low level of information. According to him, investors neither knew nor had the means to know how the money would be used. Any investor eager to increase revenues could make decisions based on personal experience and invest in any asset that had already proved worthwhile. Financial intermediaries had a key role in recommending (or merely signalling via underwriting activities) particular investment choices. The names of Baring Brothers, Murrieta and other big banking houses meant much more to investors than abstract countries. The banks' decision to enter Argentina's market served as a 'certificate of confidence' and thus as a substitute for knowledge, initiative and enterprise.

In the I 880 os, however, there were means available to obtain accurate information about the economic situation of Argentina. Table 2 shows the main sources of economic and general information available to investors. In addition to private information which individuals could obtain through particular activities such as trade or migration, there were also the reports of the Council of the Corporation of Foreign Bondholders (CFB), the Mulhall Statistics, local representatives' reports, the Statesman Yearbook, Fenn on the Funds, official documents and the press. However, these publications raised other questions. The CFB was mainly concerned with defaulting countries and did not publish any information regarding the general macroeconomic position of other borrowing countries. Rather, it collected 'press clips' and bought the official publications that contained all information relevant to investors. Still, the most detailed charter on debt figures about Argentina is published in the CFB report of I890. 9 The Statesman Yearbook often published budget figures only, and realised

8 The Economist, 23 May I89I.

9 These problems are also acknowledged in Mauro, Sussman and Yafeh (2006). About publications such as the Investors' Monthly manual, they argue that 'often the data were not updated and thus referred to previous years' (p. I6). With respect to the reports of the CFB, they recognise that they 'were focused ... on countries with payment difficulties and their coverage was somewhat haphazard' (p. I6). 
Table 2. Sources of information, other than official publications

\begin{tabular}{|c|c|c|}
\hline Source & Information disclosure & What did it say? \\
\hline $\begin{array}{l}\text { Reports of the Council of } \\
\text { the Corporation of } \\
\text { Foreign Bondholders }\end{array}$ & $\begin{array}{l}\text { Dispute on hard-dollars loan; } \\
\text { fiscal variables and state of } \\
\text { current account }\end{array}$ & $\begin{array}{l}\text { Concerns about increase of } \\
\text { expenses and debt. In I } 889 \\
\text { converted hard-dollars loan } \\
\text { were paid in paper pesos }\end{array}$ \\
\hline $\begin{array}{l}\text { Mulhall Statistics (in } \\
\text { Mulhall I886a and } \\
\text { Mulhall I886b) }\end{array}$ & $\begin{array}{l}\text { Wealth estimates, debt level, } \\
\text { demographic and geographic } \\
\text { data on the country }\end{array}$ & $\begin{array}{l}\text { I } 890: \text { increase in debt higher } \\
\text { than increase in wealth }\end{array}$ \\
\hline $\begin{array}{l}\text { Local representatives } \\
\text { (General Council of the } \\
\text { Argentine Republic and } \\
\text { South American } \\
\text { Exchange and } \\
\text { Information Office) }\end{array}$ & $\begin{array}{l}\text { General information for } \\
\text { merchants and potential } \\
\text { emigrants. }\end{array}$ & $\begin{array}{l}\text { Use the press to } \\
\text { communicate Argentina's } \\
\text { official messages }\end{array}$ \\
\hline $\begin{array}{l}\text { British representatives at } \\
\text { Buenos Aires }\end{array}$ & $\begin{array}{l}\text { General, political and social } \\
\text { and economic information. } \\
\text { State of trade and } \\
\text { immigration }\end{array}$ & $\begin{array}{l}\text { Focused on the gold } \\
\text { premium and increase in } \\
\text { public debt. Concerns } \\
\text { about the financial fragility } \\
\text { of the Government and } \\
\text { about the monetary policy }\end{array}$ \\
\hline Statesman Yearbook & $\begin{array}{l}\text { Macroeconomic and fiscal } \\
\text { variables (total indebtedness, } \\
\text { trade balance, public deficit } \\
\text { and debt service }\end{array}$ & $\begin{array}{l}\text { Argentina's figures are mostly } \\
\text { those concerning the } \\
\text { budgets. A ratio of debt } \\
\text { service to public revenue } \\
\text { can nonetheless be } \\
\text { calculated, for an average } \\
\text { of } 33 \% \text { for I } 886-9\end{array}$ \\
\hline Fenn on the Funds & $\begin{array}{l}\text { Trade test (ratio of net debt } \\
\text { per head to annual exports } \\
\text { per head). A value of the } \\
\text { ratio of more than } 4 \\
\text { (benchmark value) is } \\
\text { considered an early warning } \\
\text { signal. }\end{array}$ & $\begin{array}{l}\text { Argentina's value is } 5.35 \text {, } \\
\text { higher than well behaved } \\
\text { countries such as Belgium } \\
\text { (o.25) or Sweden (0.23) but } \\
\text { lower than other } \\
\text { problematic countries such } \\
\text { as Greece (8.49) or } \\
\text { Portugal (I3.8I) }\end{array}$ \\
\hline
\end{tabular}

Source: See text.

data on debt, deficits or prices were not systematically provided. Even the main sources, the Memorias from Argentina's Ministry of Finance, were flawed due to a number of accountability ambiguities (Duncan I984), and their publication appeared several months after a year's end. 
Table 2 also summarises what we mentioned earlier: these sources were pessimistic about the future of the country. Perhaps the most trusted source of information about Argentina's economic state at the time was Fenn on the Funds. It presented new calculations that took into account the wealth of the country - in a context where no GDP figures were available - and the interest rates on its debts, and published an indicator of debt sustainability. This indicator excluded the revenues earned from investments financed with loans. This amount was capitalised at a rate of 5 per cent and divided by the population (i.e. it was a per capita indicator). Fenn also measured the exports per capita in order to obtain a wealth indicator, although the publication recognised that this measure was far from a perfect 'proxy' for the wealth of a country. We looked at the resulting indicators for several countries in I 889. Argentina's indicator is 5.35 . This debt/exports ratio is higher than that of 'well-behaved' countries (Belgium, 0.25; Sweden, 0.23; see Flandreau and Zumer 2004) but lower than that of the problematic countries of that period (Greece, 8.49; Portugal, I 3.8 I). Argentina's ratio is also higher than that of South American countries in a comparable situation, such as Brazil (4.63) or Chile (I.I2). Besides, Fenn's compendium gave a threshold of 4 to classify countries with possible indebtedness problems and Argentina was clearly on the wrong side of that threshold.

The banks had different levels of information and for this reason one cannot generalise. However, one bank - Paribas - competed with Baring for loan business in Argentina, and was representative of the new banks that entered the Argentine market in the I880s. For the years I879 and I88I, we found several reports in the archives that aimed to inform the director of the bank about the economic situation in Argentina and about the loans contracted by the country. ${ }^{10}$ The reports pointed out the characteristics of the loans, the banks that issued them, the amount and the price of the bonds already in the market, the purpose of the loans and the guarantees for each of them. The bank made use of commercial houses in Buenos Aires in order to obtain information about the state of the market and to negotiate potential new loans for the government. In the I880s, Bemberg was an intermediary between the Argentine government and the bank. ${ }^{11}$ It sent telegrams (when a loan was negotiated) or more detailed letters about the financial movements and the country's state of affairs.

This bank possessed all the information necessary to decide whether or not to make a loan issue. It maintained a constant communication with other banks and with Bemberg. The letters, however, were only concerned with each loan or advance, and they frequently discussed market conditions for each new issue. At the same time, Bemberg was in charge of informing the bank about the movements of any potential competitor for new loans. When, after 1885 , Paribas was restricted to the business of provincial loans, the only information the group obtained about Argentina concerned the provinces with which the bank did business.

10 Paribas Archives, I02.955, Box 404.

11 Formally, it was the representative of Paribas in Buenos Aires. Bemberg was a merchant house operating in Buenos Aires 
Thus, we suspect that the information these banks obtained was at best imperfect, or, at worst, non-existent. For instance, in I 888 a syndicate formed by the Bank de Paris et des Pays Bas took firm a new loan from Cordoba province. ${ }^{12}$ The loan terms were relatively favourable to the provincial government; they gave various guarantees, such as the shares of the Provincial Bank of Cordoba, and the dividends of the Mortgage Bank of the province, which were to be created with the funds from the loan, and the revenues of the province. But, as the correspondence between the different banks that participated in the syndicate reveals, the banks were unsure of the reliability of the guarantees. In a letter addressed to the governor of the province, dated io April I 890, the banks requested information about the revenues of the province, and the loan guarantee amount. The province defaulted on its debts eight months later.

Baring's level of information is best understood by examining the history of the relationship between this bank and Argentina, which has been described by historians such as Ferns (I960, I992), Jones (I972) and Ziegler (I988). These works describe in similar terms the origins of the long-term relationship between Baring and Argentina since the country got its first loan in I 824. As Argentina defaulted on its debt in I 828, Baring, unlike other banks involved in Argentine affairs, was the only one to defend the interests of investors, succeeding eventually with an agreement in I857. This necessary relationship with Argentina's governments constituted its first source of information. Baring pursued this agreement not for the benefit of Argentina or even of the affected investors; it acted in its own interest to defend its reputation. Ziegler argues that in order to remain trusted Baring had to guarantee the revenues of investors. In fact, after I 857, eight years passed before Baring decided to issue a new loan on behalf of Argentina. Even this minor issue ( 20.55 million) was not a success, and Baring had to buy fo.2 million. Before the I 880 s, Baring only participated in two additional loans, although sharing Argentina's market with two other British banks (Morgan and Murrieta).

Apart from loans and short-term lending, Baring was also one of the main participants in the financing of Argentina's trade, and operated through the commercial houses established in Argentina. Zimmerman, Franzier and Co., from I856, and then S. G. Hale \& Co., from I 873 and during the I88os, acted as intermediaries between Argentina's government and Baring. All these activities provided the bank with information about Argentina's state of affairs. ${ }^{13}$ During the boom of the r 860 s and early I870s, Argentine bonds were in high demand in London and many of them were issued by Murrieta and Stern. In this regard, Ziegler agrees with Ferns about the particular position of Baring as a well-regarded provider of information, both directly and through the involvement of the bank in new issues. In other words, Baring possessed the information (which was expensive to acquire), but the

12 Paribas Archives, I02.955 404.

13 It was one of these enterprises, the Buenos Aires Water Supply Company, whose stock was underwritten by Baring (and failed to place), which led to Baring's fall in I 890, although the first issues took place in the late I 889 . 
benefits had to be shared with newcomers. This situation was to explode during the I 88 os.

An additional factor to be taken into account is the quality of information from the most important source, Baring's representatives in Argentina. In an apparently contradictory manner, this channel was important and efficient during the I870s, but then worsened in the $188 \mathrm{os}$, precisely at a time when it was the most necessary. A detailed examination of the Baring Archives reveals that most information Baring possessed about Argentina in the I870s and I880s came from correspondence with Nicholas Bower, one of its employees sent to Argentina after the I 873 crisis, and from some messages telegraphed when important events took place. Bower's reports covered several aspects of the country: trade, prices, immigration, financial position, banks, natural resources, tradable assets and so forth. Bower also established an almost personal relationship with Argentina's government. We have found written reports containing the exact same statistics as those published three months later in the Memorias, with additional comments expressing Bower's own point of view and derived from conversations with Argentine politicians. Between I877 and I883 Bower provided Baring with a constant flow of information about the economic situation of the state of their investments, and opportunities for new business. Financial markets were aware that Baring had information, because the latter provided news through the press whenever an extraordinary event occurred or in times of uncertainty.

However, this situation changed in 1883 for several reasons. On the one hand, there was increased competition (Jones I972; Marichal I984; Flores 2004, 2010). When new banks started issuing loans on the financial markets of Europe, the relationship between Baring and Argentina deteriorated. Jones wrote that 'Bower was at great pains to point out to the National Finance Minister the serious loss which the government had sustained through dealing with the French.' ${ }^{14}$ In fact, Ferns argues that Baring was willing to formalise its relationship with Argentina and thereby block the entry of any new competitor. In I880, Baring insisted on an 'open line of credit secured by saleable assets' and demanded that the government agree to only deal with Baring for any new loan issue. Both requests were declined by Argentina. On the other hand, the relationship between Bower and Baring also deteriorated after I 883. Baring decided to close its agency in Buenos Aires and continued to operate only through Hale \& Co. Bower continued to work with Baring but in a rather different way. From I 883, his reports became much less detailed and frequent than those he had provided between I 877 and I $883 .{ }^{15}$ Still, Baring made a final attempt at the end of I889, sending John Baring to report and evaluate Argentina's economic situation and in particular the projects in which the bank had direct interest (Ziegler I988). However, John proved to be a poor risk analyst.

14 Jones (I972, p. 5).

15 However, in Baring's accounting books, I have found that the annual wage of Nicholas Bower continued to be the same during those years ( $\mathrm{E}$ I,750 until I 885), but was reduced in I885 to £500 (ING Baring Archives, Ledgers I883-I889, Ref. IOO I 2). 
In fact, he wrongly concluded: 'Of a crash, I think there is no chance whatever ... Of their defaulting on their bonds I do not believe there to be the least chance.' ${ }^{16}$

As the Baring crisis approached, telegrams between Baring and Samuel Hale became more frequent while they were negotiating a loan with the government to avoid default. ${ }^{17}$ The main questions discussed were the conditions Baring wanted the government to meet (i.e. that the government pledge customs revenue and that payment be made half in gold). Both conditions were initially refused in Buenos Aires, but by mid I890, at Baring's insistence, the government ended up accepting.

A final question concerns the fact that Baring went bankrupt in I 890 despite its information lead. Though there is no easy answer, looking at the stock portfolios of three banks - Paribas, Rothschild and Baring - enables us to see to what extent each bank was exposed to the 'Argentine risk' in the late I 880 os. ${ }^{18}$ Table 3 shows that Baring held 9. I per cent of its portfolio in Argentine securities in I 889 (excluding its participation in syndicates, which would increase the total to 48.7 per cent in I 890 as estimated by The Economist). ${ }^{19}$ Neither of the other banks had such an amount, although Paribas's participation in syndicates amounted to 9.63 per cent in the same year. Rothschild, for instance, only held a small percentage of Argentina's securities. However, as the main underwriter of Brazilian securities, it held large amounts of these securities in its portfolio - about 8.9 per cent in I 889. After the crisis in I 892, Baring, again, held a comparable amount of Argentine securities (I 3.8 per cent). Though we cannot conclude that banks followed an unwritten 'relationship banking rule', whereby they held Io per cent of their underwritten securities in their portfolio, we may safely assert that the banks that were the most affected by defaults were the ones that had close relationships with the defaulting countries. We therefore believe that in these cases there was little scope for a conflict of interest.

\section{IV}

In a first set of tests we examine the effects of the reputation of different banks on the risk perception of investors in securities issued by these banks. Some works argue that investors take into account the fact that the less reputable banks have the most severe conflict of interest problem and the bonds they issue are therefore perceived as riskier. The more reputable banks have more to lose, and therefore the problem of conflict of interest is less severe. This first set of tests has two objectives. The first is to determine whether there is a difference between the ex-ante perceived risk associated with the bonds issued by the most reputable banks and that associated with the bonds issued by

\footnotetext{
16 Quoted in Ziegler (I988, p. 24I)

17 See ING Baring Archives, HC4.I.7I.I 890.

18 The sources are: Paribas: Rapport des commissaires et Bilans Généraux. Baring: Yearly Balance Sheets. Rothschild: Ledger Balances.

19 The Economist, I 3 June I89I.
} 
Table 3. Portfolio of different banks, 1888-9o at end of year (figures include stocks and foreign bonds, market value from banks accounting books)

\begin{tabular}{lccr}
\hline \hline & Rothschild & Paribas & Baring \\
\hline $\mathrm{I} 888$ & 0.44 & 0.38 & NA \\
$\mathrm{I} 889$ & 0.58 & $0.6 \mathrm{I}$ & $9 . \mathrm{I}$ \\
$\mathrm{I} 890$ & 0.47 & 9.63 & 48.7 \\
\hline \hline
\end{tabular}

Sources: Rothschild: Stock Ledgers Bookkeepers Department, I888-9o. Baring: Baring ING Baring archives Ref. I01370. Balances, I888, I889 . For I890: estimates from The Economist, I3 June r891. Paribas: Archives Paribas, Portefeuille Siège Social.

the other banks. The second objective is to establish whether these reputable banks acted as certifiers, which would reduce the cost of issuance of the bonds issued by these banks.

In Table 4 we present the league tables of sovereign debt underwriters and the spreads at issue per bank in the two periods, I $845-76$ and $1877-95$ (for comparison purposes, we have included the boom and bust period that preceded our period of analysis). We observe that, as contemporary records suggest, Rothschild and Baring acted as market leaders, both banks represented about half of the market in both periods. The unweighted average of the spreads at issue for Rothschild's loans is the lowest in the first period, and one of the lowest in the second. Baring follows as the second underwriter in both periods. ${ }^{20}$ During the mid-century period, Baring's bond issue spreads were lower than other issues but high in comparison to the issues made in the second period. During the I877-95 period, the spreads of issues from Baring were lower but the difference from the rest of the market is not very clear. Moreover, some banks were issuing loans that were perceived as less risky. In fact, it would be safe to assert that whereas during the mid-century period Baring differed from the other underwriters, this was no longer the case by the time the 1890 crisis occurred. We discuss this hypothesis in more detail below.

A final remark on Table 4 concerns an ex-post measure, namely, the amount of defaulting bonds underwritten by each bank. Recall that in the absence of conflict of interest, reputable banks should also have better ex-post performances than the rest. Otherwise, we would be able to assert that underwriters fooled investors by bringing securities that were perceived as 'safe' but that performed badly. During the first period, Rothschild and Baring had a market share of 5 per cent of the total amount of bonds that later defaulted. The third bank, Imperial Ottoman Bank, concentrated about 26 per cent. This bad performance may explain why its market share dropped sharply during the second period. But the striking results concern the top

20 The main results do not significantly change conducting weighted averages. 
Table 4. League tables and spreads at issue of top 10 underwriters, 1845-76 and 1877-95

\begin{tabular}{|c|c|c|c|c|c|c|c|}
\hline \multicolumn{4}{|c|}{ Period I: Mid nineteenth century } & \multicolumn{4}{|c|}{ Period II: Baring crisis } \\
\hline Bank & $\begin{array}{l}\text { Market shares } \\
\text { (in \%) of } \\
\text { amount } \\
\text { underwritten }\end{array}$ & $\begin{array}{l}\text { Unweighted } \\
\text { mean of spread } \\
\text { at issue }\end{array}$ & $\begin{array}{l}\text { Market share } \\
\text { (in \%) of } \\
\text { amount } \\
\text { underwritten in } \\
\text { default }\end{array}$ & Bank & $\begin{array}{l}\text { Market share } \\
\text { in } \% \text { of } \\
\text { amount } \\
\text { underwritten }\end{array}$ & $\begin{array}{l}\text { Unweighted } \\
\text { mean of spread } \\
\text { at issue }\end{array}$ & $\begin{array}{l}\text { Market share } \\
\text { (in \%) of } \\
\text { amount } \\
\text { underwritten in } \\
\text { default }\end{array}$ \\
\hline Rothschild & 28.98 & 2.47 & 4. I I & Rothschild & 42.70 & $2 . \mathrm{I} 4$ & 29.82 \\
\hline Baring & I 9.28 & 3.18 & 0.75 & Baring & I 2.96 & $2.9 \mathrm{I}$ & 22.58 \\
\hline $\begin{array}{l}\text { Imperial } \\
\text { Ottoman Bank }\end{array}$ & 7.09 & 6.08 & 26.92 & Hambro & 9.83 & I. 84 & 8.35 \\
\hline $\begin{array}{l}\text { Spanish Financial } \\
\text { Commission }\end{array}$ & 5.47 & 6.84 & o & $\begin{array}{l}\text { Comptoir } \\
\text { National } \\
\text { d'Escompte }\end{array}$ & $4 \cdot 43$ & I.64 & o \\
\hline $\begin{array}{l}\text { Bischoffsheim \& } \\
\text { Goldschmidt }\end{array}$ & 4.92 & $5.9 \mathrm{I}$ & $7 \cdot 36$ & Glyn Mills & 3.80 & $5 . \mathrm{I}$ & o \\
\hline Stern & 3.86 & 4.28 & o & $\begin{array}{l}\text { Russian Bank } \\
\text { for Foreign } \\
\text { Trade }\end{array}$ & $3 \cdot 52$ & 2.27 & o \\
\hline $\begin{array}{l}\text { I. Thomson, } \\
\text { T. Bonar }\end{array}$ & $3 \cdot 32$ & 3.24 & $2.7 \mathrm{I}$ & $\begin{array}{l}\text { Imperial } \\
\text { Ottoman } \\
\text { Bank }\end{array}$ & $3 . \mathrm{II}$ & 2.93 & o \\
\hline Schröder & 2.80 & 2.62 & $\mathrm{I} 3.23$ & Antony Gibbs & І. .88 & $3.9 \mathrm{I}$ & o \\
\hline Hope & 2.52 & 3.29 & $\mathrm{o}$ & Stern Bros & I. .76 & I. .98 & $4 \cdot 32$ \\
\hline J. S. Morgan & 2.38 & $4 \cdot 32$ & o & J. S. Morgan & $\mathrm{I} .45$ & I.33 & $5 \cdot 34$ \\
\hline Other banks & I9.36 & 4.08 & 44.90 & Other banks & I0.95 & 3.40 & 25.23 \\
\hline
\end{tabular}

Sources: See text. 
Table 5. Univariate tests for differences in spreads at issue between the top two banks and the rest of the market

\begin{tabular}{lcrll}
\hline \hline $\begin{array}{l}\text { Period } \\
\text { Mid century }\end{array}$ & Mean & Sample size & $t$-test & Wilcoxon test $p$-value \\
\hline Rothschild & 2.47 & 24 & $-5.72^{\star \star \star}$ & $0.000^{\star \star \star}$ \\
Baring & 3.18 & I 8 & $-2.50^{\star \star \star}$ & $0.0 \mathrm{I} 8^{\star \star}$ \\
Others & 4.38 & I I 2 & - & - \\
Baring crisis & & & & \\
Rothschild & 2.14 & 26 & $-2.8 \mathrm{I} 3$ & $0.035^{\star}$ \\
Baring & $2.9 \mathrm{I}$ & I 4 & -0.042 & 0.884 \\
Others & 2.93 & 66 & - & - \\
\hline \hline
\end{tabular}

Sources: See text.

Note: ${ }^{\star}$ denotes significance at 0.05 levels, $\star \star$ at 0.025 levels and $\star \star \star$ at 0.0 I levels.

banks' performance in the second period. The 'top three' underwrote about 60 per cent of the bonds that were to default. The above mentioned criticisms made by the press were therefore not unjustified. Nevertheless, it would be premature to draw conclusions from this result. Those of Rothschild's issues that defaulted were mostly those of Brazil in I898, that is to say Io years after the initial issue. Rothschild itself organised a bailout that provided a high profit for holders of Brazilian bonds, as demonstrated by Flandreau and Flores (20I0). Baring's Argentinian issues caused liquidity problems for the bank itself and it would therefore be irrational to assume that the bank consciously issued bad loans by selling them as good ones; but this will be discussed in the last section. Finally, defaults of the bonds issues from Hambro only concerned the Greek bonds, as otherwise this bank concentrated on the safe albeit small market of Scandinavian bonds. As we will see, Greek spreads at issue were also higher than the average spreads of Hambro's issues.

In order to formally test for differences between means of the spreads at issue, Table 5 compares the spreads at issue of Rothschild and Baring with spreads of bonds issued by other banks. The tests are the two-tailed t-test and the non-parametric Wilcoxon test. ${ }^{21}$ Our null hypothesis states that there are no differences between Rothschild and Baring's spreads at issue and that of other banks. The upper part of the table shows the results for the first period. Rothschild issues are on average I9I basis points lower than issues from the rest of the market (excluding Baring). The difference is significant at I per cent for both tests. The difference between Baring and the rest of the market, which is $\mathrm{I} 2 \mathrm{O}$ basis points, is also significant. Interestingly, these differences almost disappear in the second period. Between Rothschild and the rest of the market there is a difference of 79 basis points, and between Baring and the rest there is a 2 basis point difference. These differences

21 This kind of analysis is also conducted by Puri (I996) for the pre-Glass Steagall Act period. 
appear to be insignificant, although the Wilcoxon test shows a 5 per cent significance for Rothschild. In other words, investors did not expect Rothschild and Baring issues to be less risky.

We have complemented this analysis by examining other variables affecting spreads: economic fundamentals and bonds' particular characteristics (see the Appendix for a description of data sources). They include macroeconomic, fiscal and monetary variables, as well as variables measuring borrowers' reputation (if the borrower had a previous default), as in previous studies such as those conducted by Bordo and Rockoff (1996), Obstfeld and Taylor (2003), Flandreau and Zumer (2004), and more recently by Cameron, Gai and Yong Tan (2009). Our analysis differs from previous works in that it looks at the primary market of bonds, and thus our dependent variable is spreads at issue. This allows us to take into account the second group of independent variables, such as the identity of the underwriter, the syndicate's size, whether or not it is a new issue, whether or not the bond is secured, and the number of years since the first issue by the borrower.

We estimate the following ordinary least squares (OLS) regression:

$$
\begin{aligned}
\text { Spread }= & \beta_{0}+\beta_{1} \text { FiscVar }+\beta_{2} \text { MonVar }+\beta_{3} \text { MacroVar }+\beta_{4} \text { RepVar }+\beta_{5} \text { IssueVar } \\
& +\beta_{6} \text { BankVar }
\end{aligned}
$$

where fiscal variables (FiscVar) include the debt service to fiscal revenues ratio, the debt to GDP ratio, the public deficit to fiscal revenue ratio and the public deficit to GDP ratio. Monetary variables (MonVar) include a dummy variable that takes value I if the country has the gold standard and o otherwise; we also look for exchange rate volatility measured by the ratio between the standard deviation of the monthly nominal exchange rates to the sterling pound and its annual mean. The macroeconomic variables (MacroVar) include the inflation rate, exports to GDP ratio and a country's terms of trade measured by the deviation of log terms of trade from the panel mean. Reputation variables (RepVar) include an 'age' variable defined by the number of years since the first issue in London. It tests Tomz's (2007) hypothesis that the seasoned borrowers have more favourable market access. The second variable is a dummy which takes value I if the issuer defaulted at least once and o for a clean defaulting record. Issue variables (IssueVar) include the characteristics of the new bonds: nominal amount, maturity, number of banks in the underwriting syndicate (syndicate size), the existence of a guarantee (through a dummy variable, I if the loan if secured, o otherwise). ${ }^{22}$ Finally, the identity of the underwriter is captured in the bank variable (BankVar), with two dummy variables, one for Baring and the other for Rothschild.

Table 6 summarises the main results. The estimates show that the group of economic variables (fiscal, monetary and macroeconomic) are significant and with the expected

22 Maturity data exist for most issues. However, most Rothschild loans had no pre-specified maturity date. 
sign, with the significant exception of the terms of trade. Countries on the gold standard seem to enjoy lower spreads (the exchange rate volatility shows similar results but they are less significant and have been left out of the regressions in the table). The indebtedness level had a positive effect on spreads; furthermore, the governments of the more open economies also seem to have had more favourable access to capital markets. ${ }^{23}$ The IssueVar group has mixed results, although the defaulter dummy was always significant and with the correct sign. The age variable also had the expected sign for some regressions, but not for all of them. The maturity and amount variables were not significant. Finally, the syndicate size variable was frequently significant.

The dummy variables for the identity of the underwriter also showed mixed evidence. Most regressions showed that the Rothschild variable did have a negative effect on spreads, though this was not consistent. Baring does not appear to have any significant impact on spreads. In fact, the inclusion of macroeconomic variables, as well as the default and age variables, minimises the importance of the bankers' effect, although our sample size also decreased (due to data constraints) and the results are therefore less representative. Nonetheless, it is clear that there is a difference between Rothschild and Baring. The former seems to have a negative effect on spreads, albeit to a small degree. This is also consistent with the univariate tests, which show that spreads of Rothschild issues where lower, but the difference was not what it had been in the past. For our purposes, we may conclude that Baring had no 'reputation' or 'certification' effect. The bank was selling risky securities, just as the other banks did. Investors fixed prices according to the risk.

\section{Underwriting fees: the case of the 1890 agreement}

One way to know whether conflicts of interest existed in the late I 880 os is to look at credit risk perception of financial intermediaries and investors. In normal, crisis-free times, spreads or securities risk premia should behave in a manner similar to underwriter fees. In times of 'near crisis', in a context of information asymmetries, this correlation breaks down and fees can react more rapidly than spreads. ${ }^{24}$ The reason for this can be found in the vast literature on the factors determining underwriting fees. ${ }^{25}$ They can be classified into three groups: bonds' characteristics, underwriting's market structure (whereby competition reduces fees, see Gandes et al. I999) and credit quality. Previous studies have shown that the market for risky bonds is smaller and less liquid than the market for risk-free bonds, which makes their placement more difficult. In the event of default, the financial intermediary's reputation would suffer. Moreover, the higher the risk of a new issue, the more difficult it becomes to estimate the issue price; compensation is naturally required for the additional effort (Livingston, Pratt and Mann I995; Melnik and Nissim 2006). Thus, underwriting

23 The debt service to fiscal revenue ratio also has the expected sign and resulted significant in most of the regressions, but due to space constraints results are not shown. They are available upon request.

${ }^{24}$ Empirical evidence of this for the I990s sovereign debt crises can be found in Nieto-Parra (2009).

25 Pioneering studies were performed by Cohan (I96I), West (I967) and Mendelson (I968). 
Table 6. Multivariate tests: OLS Regressions. Dependent variable: spreads at issue

\begin{tabular}{|c|c|c|c|c|c|c|}
\hline Variable & Regression I & Regression 2 & Regression 3 & Regression 4 & Regression 5 & Regression 6 \\
\hline Constant & $3.5 \mathrm{I}^{\star \star \star}(6.69)$ & $3.64^{\star \star \star}(6.88)$ & $2.22^{\star \star \star}(5.2 \mathrm{I})$ & $2.708 \star \star \star(5.45)$ & $2.32^{\star \star \star}(4.43)$ & $2.09^{\star \star \star}(3.73)$ \\
\hline $\begin{array}{l}\text { Maturity (in } \\
\text { years) }\end{array}$ & & & & $-0.005(-0.67)$ & & \\
\hline $\begin{array}{l}\text { Amount (in } \\
\text { I, ooo of } f \text { ) }\end{array}$ & & & & $-\mathrm{I} .75 \mathrm{E}-6(-0.07)$ & & \\
\hline Syndicate size & $-0.44^{\star \star}(-\mathrm{I} .68)$ & $-0.5 \mathrm{I}^{\star \star}(-\mathrm{I} .85)$ & & & & \\
\hline Defaulter & 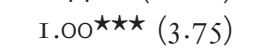 & I.IO & $0.75^{\star \star \star}(2.77)$ & & & \\
\hline Age & $-\mathrm{O} . \mathrm{OI} \star \star(-\mathrm{I} .67)$ & $-0.06^{\star \star \star}(-2.33)$ & -0.00 I $(-0.09)$ & & O.OI (I.2O) & O.OI (I.O3) \\
\hline Secured & & & $0.94^{\star \star \star}(3.3 \mathrm{I})$ & & & \\
\hline Rothschild & $-0.50^{\star \star}(-1.67)$ & & $-0.054(-\mathrm{I} .87)$ & 0.18 (0.5I) & $-0.48^{\star \star}(-\mathrm{I} .74)$ & \\
\hline Baring & & $0.08(0.22)$ & $-0.03(-0.09)$ & $0.25(0.83)$ & & $0.52^{\star \star}(\mathrm{I} .66)$ \\
\hline $\begin{array}{l}\text { Deficit to } \\
\text { revenue }\end{array}$ & & & & $-\mathrm{I} .15^{\star}(-2.58)$ & & \\
\hline Gold Dummy & $-0.88^{\star \star \star}(-2.74)$ & $-\mathrm{I} .02^{\star \star \star}(-3 . \mathrm{I} 9)$ & $-0.05^{\star \star}(-$ I.6I $)$ & & $-0.34(-\mathrm{I} .26)$ & $-0.27(-0.99)$ \\
\hline Reserves to MI & & & & $-\mathrm{I} .76^{\star \star \star}(-3.24)$ & & \\
\hline Terms of trade & $1.22^{\star \star}(2.15)$ & I.08.$\star($ I.90) & 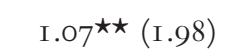 & & & \\
\hline Debt to GDP & & & & & $0.59^{\star \star \star}(2.78)$ & $0.53^{\star \star}(2.56)$ \\
\hline Exports to GDP & & & & & $-5.27^{\star \star \star}(-3.6 \mathrm{I})$ & $-4.5^{\star \star \star \star}(-3.12)$ \\
\hline $\mathrm{R}-2$ & 0.346 & 0.325 & 0.407 & $0.57 \mathrm{I}$ & 0.306 & 0.236 \\
\hline $\begin{array}{l}\text { Number of } \\
\text { observations }\end{array}$ & 89 & 89 & 89 & 33 & 58 & 58 \\
\hline
\end{tabular}

Note: t-statistics in parentheses. ${ }^{\star}, \star \star$ and $\star \star \star$ denote significance at $10 \%, 5 \%$ and $1 \%$ levels respectively.

Sources: See text. 
fees and secondary market prices depend on the same variables: an economic shock may cause the prices of that country's bonds to fall. When a government presents a higher risk of default, the underwriters charge them higher fees on new issues ceteris paribus. Flandreau et al. (2009a) show evidence about the long-term relationship between fees and spreads at issue in sovereign debt markets for the last 200 years and find a constant, negative relation between both variables.

A final question concerns the mechanisms through which new information could have an immediate impact on spreads and fees. If information is public, then both variables should behave in the same way (though the elasticities of each variable to new events may differ). Now consider, for instance, the scenario in which a bank, willing to issue a new loan on behalf of the government of Argentina, suddenly receives a telegram from its agent in Buenos Aires about a new estimate of a higher deficit than previously expected. This is not a hypothetical case: as we mentioned above, figures about fiscal variables could take as long as three months to be published in the official Memorias or in the press. This negative shock may make the success of a new issue more uncertain, and the bank may therefore automatically adapt its underwriting fee to compensate for the increased risk, but would be unwilling to lower the issue price which would send a negative signal to the markets, thereby affecting secondary market prices and increasing the probability of failure of the new issue. This fact would be, per se, evidence of conflict of interest. In other words, selling risky securities is no evidence of 'bad behaviour' as long as there is a market for them. But selling risky securities as if they were good is a different story, and this explains why regulatory authorities have been interested in underwriting fees in later periods, when banks were suspected of inappropriate behaviour. ${ }^{26}$ We have gathered data on fees - for the I877-95 period - from debt contracts, archives and secondary literature. Sources are described in the Appendix. Figure I shows the positive relationship between spreads at issue and underwriting fees during the I 880 os $^{27}$ At first glance, Argentina does not seem to be an outlier. ${ }^{28}$ But now, let us consider the case for the I 890 planned bailout. Two additional loans were negotiated - though eventually not issued - between Argentina, Uruguay and Baring as early as March I890. The resulting debt underwriting fees were 9.6 for Uruguay and I2.4 for Argentina. ${ }^{29}$ Both observations are outliers, and do not correspond to the normal relation between fees and spreads; for both observations, the fees were affected more rapidly by Argentina's bad economic situation. In other words, at the only time when Baring could have taken advantage of its information lead, the bank was

26 For a discussion of this argument for the I920s see Flandreau, Gaillard and Panizza (20io).

27 I have also run a regression to determine the relationship between underwriting fees and spreads. Results are the following (t-stats in parentheses): $f e e=0.13(0.12)+1.9(4.8 \star \star \star) \star s p r e a d ; R^{2}=0.48$.

28 The main outlier of the regression is the I3\% underwriting fee of China's $6 \%$ loan of I 885 .

29 The Bank of Uruguay was the first to suffer a crisis which triggered a banking panic that expanded to banks in Argentina (I2 July I890, The Economist). Baring negotiated a loan parallel to that negotiated with Argentina's government. The price at issue was not agreed in the contracts, though I have estimated it as a simple average of Argentina's similar bonds on the secondary market. 


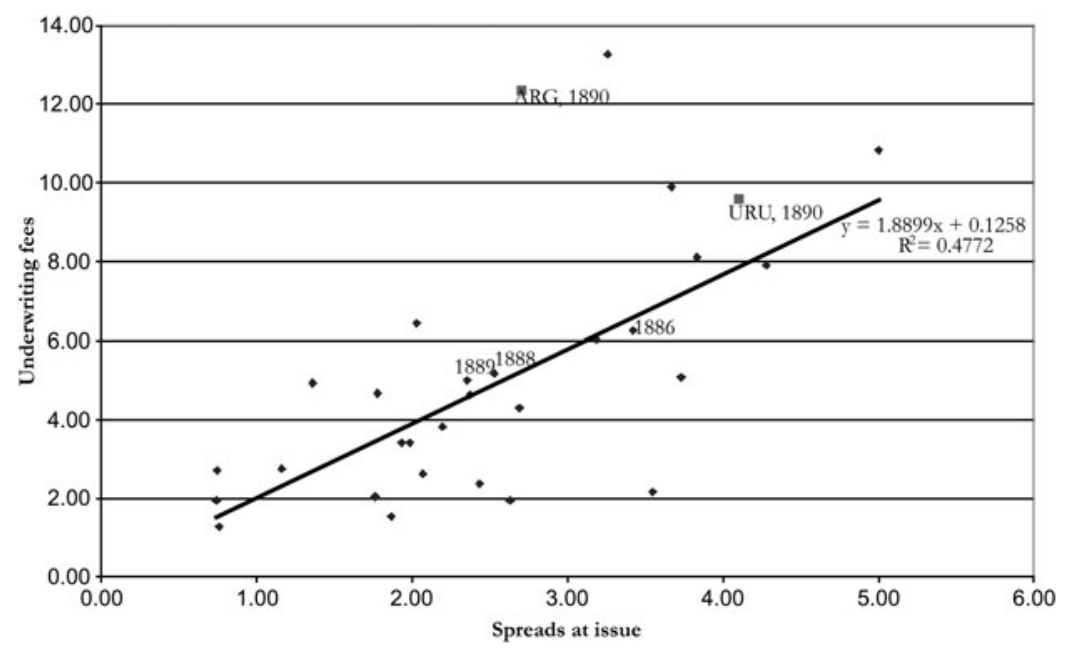

Figure I. Underwriting fees and spreads at issue

Sources: See text and Appendix.

overwhelmed by a wave of negative shocks (and publicly known) that lead to Argentina's accelerated collapse.

An examination of the correspondence between Baring and its agents in Buenos Aires shows no evidence that Baring sought to hide information from investors. Instead, the correspondence suggests that Baring was confident that default could be avoided with the planned bailout. The conditions of the I 890 contract forced the country to modify its economic policy. Baring imposed three conditions: no further issues of paper money, until the gold premium reached a level of I 40 . The second was the prohibition of further borrowing from external sources for two years. Finally, half of the customs revenues had to be collected in gold pesos, reinforcing the government's capacity to service its debt.

From the analysis of the sources of information available to investors we also know that they could have known of the problems facing Argentina even though they had less information than banks. The tendency of financial intermediaries, however, was to send confidence signals by issuing new bonds as demand existed. This behaviour was motivated by a desire for short-term gains. Baring, in contrast, relied on a long-term relationship and had different incentives from those of competing banks.

The information model that prevailed at the time began to change in the early I 890s. Capital exports came to a 'sudden stop' during the I 890 , and the information structure began to change. The reports of the CFB began to be more detailed, other banks followed Credit Lyonnais's unit of analysis, and the financial press experienced a new boom. Argentina was excluded from capital markets for some years and Baring 
subsequently returned to business as the only merchant bank for the issues of the country's government, recovering its quasi-monopolistic position. Argentina did not experience additional crises before World War I. Nonetheless, even in this new context of increased information availability (and thus higher 'transparency'), there continued to be financial crises throughout the world.

Submitted: 3 May 2010

Revised version submitted: 15 September 2010

Accepted: 30 October 2010

First published online: 4 May 2011

\section{References}

ANG, J. S. and RICHARDSON, T. (1994). The underwriting experience of commercial bank affiliates prior to the Glass-Steagall Act: a re-examination of evidence for passage of the act. Journal of Banking and Finance, 18, pp. 35I-95.

BERTINO, M. and BERTONI, R. (2004). Más de un siglo de deuda pública uruguaya: una historia de ida y vuelta. Nordic Journal of Latin American and Caribbean Studies, 34, pp. I23-50.

BÉRTOLA, L. (1998). El PBI de Uruguay, I870-1936, y otras estimaciones. Documento de Trabajo 7/98, Unidad Multidisciplinaria-Facultad de Ciencias Sociales, Universidad de la Republica. Montevideo, Uruguay.

BLATTMAN, C., HWANG, J. and WILLIAMSON, J. G. (2004). The impact of the terms of trade on economic development in the periphery, I870-1939: volatility and secular change. NBER Working Paper I0600, National Bureau of Economic Research.

BOLTON, P., FREIXAS, X. and SHAPIRO, J. (2007). Conflicts of interest, information provision, and competition in the financial services industry. Journal of Financial Economics, 85, pp. 297-330.

BORDO, M. and ROCKOFF, H. (I 996). The gold standard as a 'Good Housekeeping seal of approval'. Journal of Economic History, 56, pp. 389-428.

BRAUN, J., BRAUN, M., BRIONES, I. and DÍAZ, J. (2000). Economía chilena I 8 Io-I995: estadísticas históricas. Documento de Trabajo I87, Pontificia Universidad Católica de Chile, Santiago.

CAIRNCROSS, A. K. (I953). Home and Foreign Investment, 1870-1913: Studies in Capital Accumulation. Cambridge: Cambridge University Press.

CAMERON, G., GAI, P. and YONG TAN, K. (2009). Sovereign risk in the classical gold standard, The Economic Record, 85, pp. 40I-I6.

CARMAGNANI, M. (I994). Estado y mercado: la economía pública del liberalismo mexicano, 1850-1911. México: Fondo de Cultura Económica.

CARTER, R. B. and MANASTER, S. (I990). Initial public offerings and underwriter reputation. Journal of Finance, 45, pp. I045-64.

CERRO, A. M. (2000). La conducta cíclica de la economía argentina y el comportamiento del dinero en el ciclo económico. Argentina I820-I998. Mimeo.

CLARKE, H. (I 878). On the debt of sovereign and quasi-sovereign states, owing by foreign countries. Journal of the Statistical Society of London, 4I/2, pp. 299-347.

COHAN, A. B. (I96I). Cost of Flotation of Long-Term Corporate Debt. Chapel Hill: University of North Carolina Press.

CORTES CONDE, R. (1979). El progreso Argentino 1880-1994. Buenos Aires: Ed. Sudamericana.

CORTES CONDE, R. (I989). Dinero, deuda y crisis: evolución fiscal y monetaria en la Argentina, 1862-1890. Buenos Aires: Ed. Sudamericana.

COSTELOE, M. P. (2003). Bonds and Bondholders, British Investors and Mexico's Foreign Debt, 1824-1888. Westport, CT: Praeger.

DELLA PAOLERA, G. (I988). How the Argentine economy performed during the international gold standard: a re-examination. PhD Dissertation: University of Chicago. 
DELlA PAOLERA, G. (I994). Monetary and banking experiments in Argentina, I86I-I930. Universidad Torcuato di Tella Working Paper I I.

DELLA PAOLERA, G. and TAYLOR, A. (200I). Straining at the Anchor: The Argentine Currency Board and the Search for Macroeconomic Stability, 1880-1935. Chicago: University of Chicago Press.

DRITSAS, M. (I993). Foreign capital and Greek development in a historical perspective. Uppsala Papers in Economic History, Working Paper no.Io.

DUNCAN, T. (1984). La política fiscal durante el gobierno de Juarez Célman, i886-ı89o. Desarrollo Económico, 23, pp. I I-34.

EICHENGREEN, B. (I999). The Baring crisis in a Mexican mirror. International Political Science Review, 20, pp. 249-70.

FENN, C. (I 887). Fenn on the Funds. London: Effingham Wilson.

FERGUSON, N. (1998). The World's Banker: The History of the House of Rothschild. London: Weidenfeld and Nicholson.

FERNS, H. S. (1960). Britain and Argentina in the Nineteenth Century. Oxford: Clarendon Press.

FERNS, H. S. (I992). The Baring crisis revisited. Journal of Latin American Studies, 24, pp. 24I-73.

FLANDREAU, M. (I998). Caveat emptor: coping with sovereign risk without the multilaterals. CEPR Discussion Paper 2004.

FLANDREAU, M. (2003). Crises and punishment: moral hazard and the pre-I9I4 international financial architecture. CEPR Discussion Paper 3742.

FLANDREAU, M. and FLORES, J. (2009). Bonds and brands: lessons from the I82os. Journal of Economic History, 69, pp. 646-84.

FLANDREAU, M. and FLORES, J. (20I0), Hamlet without the Prince of Denmark: relationship banking and conditionality lending in the London market for government debt, I8I5-I9I3. CEPR Discussion Paper 79I5.

FLANDREAU, M., FLORES, J. H., GAILLARD, N. and NIETO-PARRA, S. (2009a). The end of gatekeeping: underwriters and the quality of sovereign bond markets, I8I5-2007. NBER Working Paper I 5 I 28.

FLANDREAU, M., FLORES, J. H., GAILlARD, N. and NIETO-PARRA, S. (2009b). Two centuries of government bond underwriting, mimeo.

FLANDREAU, M., GAILLARD, N. and PANIZZA, U. (20I0). Conflicts of interest, reputation, and the interwar debt crisis: banksters or bad luck? HEID Working Paper 02/20I0.

FLANDREAU, M. and ZUMER, F. (2004). The Making of Global Finance, 1880-1913. Paris: OECD.

FLORES, J. (2004). Lorsque le leader suit la foule: la crise Baring dans une perspective microéconomique. PhD dissertation, Sciences-Po, Paris.

FLORES, J. (2010). Lending booms, underwriting and financial intermediaries. Law and Contemporary Problems, 73, pp. I29-50.

FORD, A. G. (I962). The Gold Standard, 1880-1914: Britain and Argentina. Oxford: Clarendon Press.

FORD, A. G. (I97I). British investment in Argentina and long swings. Journal of Economic History, 3I, pp. 650-63.

GANDES, A., PURI, M. and SAUNDERS, A. (I999). Bank entry, competition and the market for corporate securities underwriting. Journal of Financial Economics, 54, pp. I65-95.

GIRAULT, R. (1973). Emprunts russes et investissements français en Russie, 1887-1914. Paris: Armand Colin.

JENKS, L. H. (1927), The Migration of British Capital to 1875. New York: Knopf.

JONES, C. A. (I972). European bankers and Argentina, I880-I890. Working Papers Business Imperialism Series, Centre of Latin American Studies, University of Cambridge, 3.

JOSLIN, D. (1963). A Century of Banking in Latin America: to Commemorate the Centenary in 1962 of the Bank of London \& South America Limited. New York: Oxford University Press.

KINDLEBERGER, C. P. (1978). Manias, Panics, and Crashes: A History of Financial Crises. New York: Basic Books.

KLOVLAND, J. T. (I994). Pitfalls in the estimation of the yield on British Consols, I850-I9I4. Journal of Economic History, 54, pp. I64-87.

KLOVLAND, J. T. (2004). Bond markets and bond yields in Norway I820-2003. In Ø. Eitrheim, J. T. Klovland and J. F. Qvigstad (eds.), Historical Monetary Statistics for Norway 1819-2003. Norges Bank Occasional Papers no. 35. Oslo: Norges Bank. 
LIEDTKE, R. (2006). N. M. Rothschild E Sons: Die Kommunikation in Bannkenwesen im Europa des 19. Jahrhunderts. Cologne: Böhlau Verlag.

LIVINGSTON, M., PRATT, H. and MANN, C. (I995). Drexel, Burnham, Lambert's debt issues. Journal of Fixed Income, 5, pp. 58-75.

MARICHAL, C. (I984). Los banqueros europeos y los empréstitos argentinos: rivalidad y colaboracion, I880-I 890. Revista de Historia Economica, 2, pp. 47-82.

MAURO, P., SUSSMAN, N. and YAFEH, Y. (2006). Emerging Markets and Financial Globalization Sovereign Bond Spreads in 1870-1913 and Today. Oxford: Oxford University Press.

MEISSNER, C. (2005). A new world order: explaining the international diffusion of the gold standard, I 870-I9I 3. Journal of International Economics, 66, pp. 385-406.

MELNIK A. and NISSIM, D. (2006). Issue costs in the Eurobond market: the effects of market integration. Journal of Banking and Finance, 30, pp. I 57-77.

MENDELSON, M. (I968). Determinants of underwriters' spreads on tax-exempt bond issues: comment. Journal of Financial and Quantitative Analysis, 3, pp. 2 I 5-24.

MUlHALL, M. G. (I 886a). Handbook of the River Plate. Buenos Aires: Buenos Ayres Standard.

MULHALL, M. G. (I886b). Mulhall's Dictionary of Statistics. London: G. Routledge and Sons.

NIETO-PARRA, S. (2009). Who saw sovereign debt crises coming? Economia, Io, pp. I25-69.

OBSTFELD, M. and TAYLOR, A. M. (2003). Sovereign risk, credibility and the gold standard: I870-I9I3 versus I925-3 I. Economic Journal. II3, pp. 24I-75.

PURI, M. (I996). Comercial banks in investment banking: conflict of interest or certification role? Journal of Financial Economics, 40, pp. 370-40I.

SCHNEIDER, J., SCHWARZER, O. and DENZEL, A. (I997). Währungen der Welt, vol. VII. Stuttgart: Franz Steiner Verlag.

STONE, I. (1999). The Global Capital Export from Great Britain, 1865-1914: A Statistical Survey. New York: St Martin's Press.

SUZUKI, T. (I994). Japanese Government Loan Issues on the London Capital Market, 1870-1913. London: Athlone Press.

TOMZ, M. (2007). Reputation and international cooperation: Sovereign Debt Across Three Centuries. Princeton: Princeton University Press.

WEST, R. (1967). Determinants of underwriters' spreads on tax-exempt bond issues. Journal of Financial and Quantitative analysis, 2, pp. 24 $\mathrm{I}-63$.

WIRTH, M. (I893). The crisis of I890. Journal of Political Economy, I, pp. 214-35.

ZIEGLER, P. (I988). The Sixth Great Power: Barings, 1762-1929. London: Collins.

\section{Sources}

Annual Reports of the Council of the Corporation of Foreign Bondholders (London: I883-93).

Burdett's Stock Market Official Intelligence (London, I880-90).

Crédit Lyonnais' Historical Archives: Boxes DEEF 73404-8 and DEEF 734I 5 (Paris).

Departamento de Hacienda. Memoria del departamento de Hacienda presentada al Honorable Congreso Nacional. Buenos Aires: Sud-América, I880-93.

Kurt Schuler (ed.), 'Historical financial statistics: data notes', original version 24 April 20 Io; updated version of June 20 Io viewed at Historical Financial Statistics Website, www.centerforfinancialstability.org/hfs_data. php.

ING Baring Archives: Box Hc4.I.7I, Box Hc4 I. I 3. Ledgers, I883-93 (London).

Paribas Archives: 102.955, Box 404 (Paris).

Statesman Yearbook (London, I $885-90)$.

The Economist supplement: Investors' Monthly Manual (London: various years) 


\section{Appendix. Data sources}

\section{Primary market variables}

(I) Bond data: the multivariate analysis of the ex ante tests of conflict of interest includes all the public offerings of foreign government sovereign debt on London excluding pure conversions (for which there was no price at issue). The complete list is taken from Suzuki (2004). That list includes data on nominal amounts and underwriters' identity. It has been revised with data from the Investors' Monthly Manual (IMM), The Times (London), Burdett's Stock Market Official Intelligence and debt contracts, from which we had data for prices at issue, maturity, underwiters' syndicate size and bonds' guarantees. A complete list since the beginning of the nineteenth century has been constructed with data from Clarke (1878), CFB (I874) and the London Times with which we construct the variable age (number of years since first issue in London) and the dummy variable 'New Borrower', equal to one if the borrower issues for the first time a loan in London, o otherwise. The countries included in the list are the following: Argentina, Brazil, Bulgaria, Chile, China, Cuba, Denmark, Egypt, Greece, Holland, Hungary, Italy, Mexico, Nicaragua, Norway, Persia, Portugal, Russia, Salvador, Santo Domingo, Spain, Sweden, Turkey, Uruguay, USA.

(2) Spreads at issue: defined as the difference between the yield on long-term gold or sterling government bonds measured by the coupon-price ratio and the yield of UK consols (from Klovland I994).

(3) Fees: China: HSBC Archives, Greece: Dritsas (I993), Japan: Suzuki (I994). Data on Norway's loans are from Klovland (2004) but we have excluded the first loan as data are not consistent with the issue price; data on Argentine, Brazilian and Chilean fees are from Flores (2004). Russia's fees are from Girault (I973) and from archives (Rothschild, Paribas and ING Baring). These archives were also used to obtain other fees for Italy, Portugal and Uruguay.

\section{Macroeconomic variables}

(4) Gold dummy variable: Flandreau and Zumer (2004) for the period I 880-95 for the following countries: Argentina, Brazil, Chile, Denmark, Greece, Holland, Hungary, Italy, Norway, Portugal, Russia, Spain and Sweden. Otherwise: Meissner (2005) and for countries that issued during I 877-9, Obstfeld and Taylor (2003).

(5) Volatility of exchange rate: Flandreau and Zumer (2004) for the same countries and period than above. We have computed volatilities for exchange rates from the following sources: Chile from Flores (2004), otherwise Schneider et al. (I997).

(6) Inflation: Flandreau and Zumer (2004) and Obstfeld and Taylor (2003) as in (4). Chile: Braun et al. (2000). Turkey: Schuler (2010). Uruguay: Bértola (1998). 
(7) Reserves and MI: Flandreau and Zumer (2004) for countries and period as in (4). Chile: Braun et al. (2000).

(8) Deficits, revenues and public debt: Flandreau and Zumer (2004) and Obstfeld and Taylor (2003) as in (4). Chile: Braun et al. (2000). Mexico: Carmagnani (1994). Uruguay: Bertino and Bertoni (2004).

(II) Debt service: Flandreau and Zumer (2004). Chile: Braun et al. (2000). Mexico: Carmagnani (I994).

(I2) Nominal GDP: Uruguay: Bértola (1998). Chile: Braun et al. (2000). Otherwise Flandreau and Zumer (2004) and Obstfeld and Taylor (2003) as in (4).

(I3) Terms of trade: defined as in Obstfeld and Taylor (2003). The variable measures the deviation of $\log$ terms of trade from the panel mean. Source for the data is Blattman, Hwang and Williamson (2004).

(I4) Exports: same as (8). 